\title{
Groundwater Resources as a Resilient Alternative for Irrigation in the Upper West Region of Ghana - A Study of Groundwater Potential
}

\author{
Shaibu Abdul-Ganiyu ${ }^{1}$ and Kpiebaya Prosper ${ }^{1 *}$ \\ ${ }^{1}$ University for Development Studies, School of Engineering, \\ P. O. Box 1338TL, Nyankpala, Ghana, West Africa
}

\begin{abstract}
Groundwater use has increased substantially for both domestic and agricultural purposes in the growing communities of Ghana. The way climate change has treated agriculture in some parts of Africa; it can possibly sabotage food security if policies on groundwater irrigation are not adopted. Geology of the Birimian is known for its high-moderate groundwater potential. This kind of formation occurs in the Northwestern corner, the middle portion and some parts in southern Ghana. Previous study has suggested that there are more than $\mathbf{7 7 9}$ functional boreholes that exist within the study area. The groundwater potential within the study area was studied using typical hydrogeological factors such as; groundwater resistivity, overburden thickness, borehole success rate and groundwater pumping rate. Resistivity values between 38.480 ohm.m - $103.740 \mathrm{ohm} . \mathrm{m}$ showed areas of fresh to brackish groundwater resource having a saturated thickness ranging from $13.79 \mathrm{~m}$ to $16.27 \mathrm{~m}$. Information regarding borehole depth indicates that places of high SWL $(20.60 \mathrm{~m})$ probably has shallow depth and places of low SWL $(18.75 \mathrm{~m})$ are likely to have deeper depth. Generally, areas within Tegberi and Tumu are known for its high success rate. The storage capacity and the extractble storage were estimated to be approximately $134.9 \times 10^{3} \mathrm{~km}^{3}$ and $53.23 \times 10^{3} \mathrm{~km}^{3}$ respectively for the aquifer basement complex of the 35 boreholes. The research targeted areas of high groundwater success rate so as to minimise the gap in the computation that may be affected as a result of the dry boreholes. The pumping rate showed that large quantity of groundwater was discharged from the boreholes; hence the exploration of groundwater as an alternative water supply for irrigation and agricultural production within the Upper West Region might be feasible.
\end{abstract}

Keywords:- Birimian, VES, Groundwater, Hydrogeology, SWL and Pumping.

\section{INTRODUCTION}

Groundwater potential within some African countries is gaining more recognition as well as been an invaluable unexplored resource for irrigated-agriculture (Masiyandima and Giordano, 2007; Giordano, 2006). However, scarcity of water supply for dry season agriculture (irrigation) is familiarly acute, prompting most Sub-Saharan Africa countries to depend on rain-fed agriculture which can threaten food security now and time to come (Forkuor et al., 2013). MacDonald et al. (2012) in a research developed groundwater potential maps which estimated the total freshwater resources as groundwater in Africa to be 0.68 billion $\mathrm{km}^{3}$ despite the $9 \%$ of the total world freshwater resource (Trenberth et al., 2007). Pavelic et al. (2012), in reviewing the groundwater availability in Sub-Saharan Africa countries stated the abundance of groundwater resource in this area of the globe and the criticality of groundwater for economic development in SSA countries. Continentally, Africa's groundwater resource per inhabitants is estimated to be $5000 \mathrm{~m}^{3} /$ year greater than Asian which is $3400 \mathrm{~m}^{3} /$ year. There are three (3) justified reasons why groundwater can a suitable source for irrigation: 1) Its storage volume is immeasurable 2) Superior quality compared to surface water and 3) Affordable for underprivileged communities' infrastructural-wise (Adelana and MacDonald, 2008). In spite of this groundwater is underexploited for irrigatedagriculture in the SSA countries.

Simultaneously, implementing alternatives and policies like groundwater irrigation could minimise poverty, boost food security and make it resilient to changes in climatic patterns and variability (UNEC, 2011). The Upper West Region has challenging conditions for farmers, with extreme temperatures, uncertain rainfall and eroded soils thereby affecting crop yields. This research brings to the fore how geophysical and hydrogeological techniques were used to delineate potential sites to implement these interventions for irrigational schemes, planning irrigation schedule and optimizing crop yield. In 2012, one of the objectives of the Savannah Accelerated Development Authority (SADA) was to drill boreholes for agricultural farms in the Northern Section of Ghana especially the Upper West Region. Most of these boreholes were drilled in mango plantation to enhance mango productivity in the Upper West Region.

Recent studies have proven that climatic conditions has offset rainfall patterns and hence endangering agriculture and food security (Bouraoui et al., 1999) meanwhile, SSA has substantial potential which can support dry season farming (Giordano, 2006). The question that is often asked is why groundwater is underexploited in SSA? This can be attributed to the fact that information regarding groundwater exploration are not precise and predictive enough to explore, as a result of complex geology varying from one setting to another. The purpose of this research is to contribute and update literature by 
quantifying the groundwater storage capacity and predict viable sites for future irrigation schemes within the research area.

Groundwater survey can be studied using several geophysical techniques; the famous of them are the ElectroMagnetic Induction (EMI) which operates on the principle of electrical conductivity while the Electrical Resistivity (ER) operates on the principle of electrical resistivity. These methods especially the ER, estimates zones (lithology) of high fractures and properly weathered formation. Areas of low resistivity were considered for drilling per this study. However, preference was given to the electrical resistivity methods because of it multipurpose use; in detecting groundwater as well as characterizing the lithological units using Schlumberger configuration array. The type of drilling method popularly used in the Area of Study to access groundwater resources is the air rotary drilling.

The main objective was to establish whether the exploration of groundwater for irrigation would be feasible analysing data gathered from resistivity and groundwater, storage capacity and yield from the pumping test data.

\section{NATURE OF STUDY AREA}

The description of the study area is to highlight distinct characteristics and to complement the hydrogeological synthesis in the area.

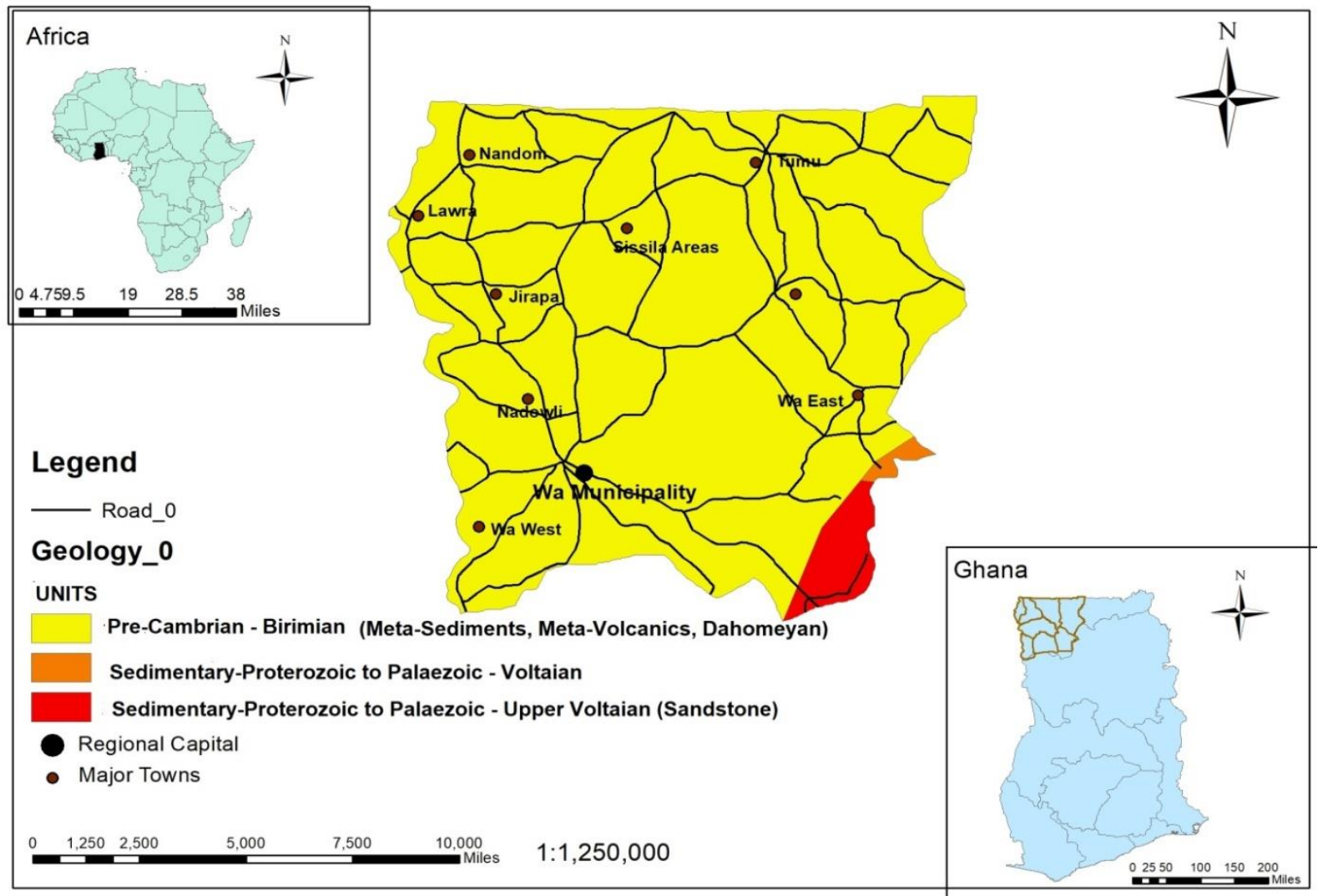

Fig 1:- Study area showing the geology, major towns and road network

The study area is situated in the Northwestern corner of the country, bounded to the North by Burkina Faso in the West by Ivory Coast, in the South by the Northern Region and in the East by Upper East region. The Upper West Region covers roughly an area of $18,476 \mathrm{~km}^{2}$ approximately $7.7 \%$ of the total land area of Ghana.

The climate is characterised by an intensive quarterly rainfall and a long dry period from mid-November to the beginning of May. Vegetatively, the region is divided into two ecological zones: the Guinea Savannah in the Southern part and the woodland Savannah in the Northern and Northeastern parts of the study area. Typical majority of the study area covers the Guinea savannah, with high density of tree species. The low population densities (trees) have permitted a remarkable conservation of savanna vegetation. Typical tree species are the Shea, Vitellaria paradoxa, the locust, Parkia biglobosa, the silk-cotton, Ceiba pentandra and the mahogany, Khaya senegalnesis. Baobabs, Adansonia digitata, are very unique of early human settlement of introduced trees, the mango, Mangifera indica and neem, Azadirachta indica are common in villages and also found on escapes in uncultivated areas. Data from Ghana Soil Research Institute (SRI, 2006), classified soils found in the Upper West Region to be predominantly: Leptosols, Lixisols, Gleysols and Ferralsols. Moreover, Vertisols and Fluvisols are found in less amounts in the areas around the Red and White Volta. 


\section{Geological and Hydrogeological settings}

The underlying geology is a makeup of the Precambrian rocks and Paleozoic Sedimentary rocks. The Precambrian rocks comprise the Upper, Middle and Lower Birimian attributed with granitic activities. A small area of the Buem is found around the Southeastern part of the study area. The Birimian super-group is made up of schist, phyllite, gneiss, pegmatites and quartzites which are impermeable. The Paleozoic Sedimentary is about 2\% in the area consisting of Sandstone, Shale and Mudstone.

The lithology of the Birimian formation generally has poor interconnectivity of pores resulting in low permeability. Groundwater in the context of hydrogeological setting is determined by effective interconnected-pores designed by the effect of rock decomposition (chemical processes). This decomposition has advance importance on the capacity of groundwater (Larsson, 1984). The yielding zone of groundwater is within the lower and upper part of the saprolitic zone, they balance each in terms of yield and storage. Areas within the Birimian sub-group exhibit in-depth weathering (about 22 $\mathrm{m}$ ) than the granitic areas of (about $16 \mathrm{~m}$ ) because of poor shearing in rocks (Nathan and Harris, 1970). This will eventually result in shallow water-tables and low yielding boreholes in the granitic areas. Pegmatities and Quartz veins intrusions are recognised for its maximum yield of groundwater. The overburden is unsaturated in most places and would probably store groundwater in lesser amounts (Acheampong and Hess, 1998).

\section{DATA AND METHODOLOGY}

Some hydrogeological factors were studied to provide suitable information on the tendency of adopting groundwater for irrigation, these include; groundwater geophysics, borehole loggings, pumping rate of boreholes and SWL of boreholes. The methods employed in relation to the factors for this paper includes; Vertical Electrical Sounding (VES) and Schlumberger profiling array for the groundwater geophysics, rotary drilled boreholes and Constant Rate Test (CRT-6 hours) for pumping rate.

\section{A. Groundwater Geophysics}

Vertical Electrical Sounding (VES) is one of the most popular groundwater exploration tools; under this method 35 VES points were picked. The measurements were obtained during the field survey using an average transverse length of $1.0 \mathrm{~km}$ and $400 \mathrm{~m}$ current electrode spacing with the Schlumberger configuration. The Schlumberger configuration can be useful in profiling lateral resistivity variation which can help in studying the lithology and also use to study groundwater occurring zones. The current electrode and potential electrode were kept at same relative spacing and the whole configuration was moved progressively. To detect groundwater existence from VES data, a detail and rigorous study of the pattern of apparent resistivity values (ohm.m) must be plotted either on field or using geophysical software package.

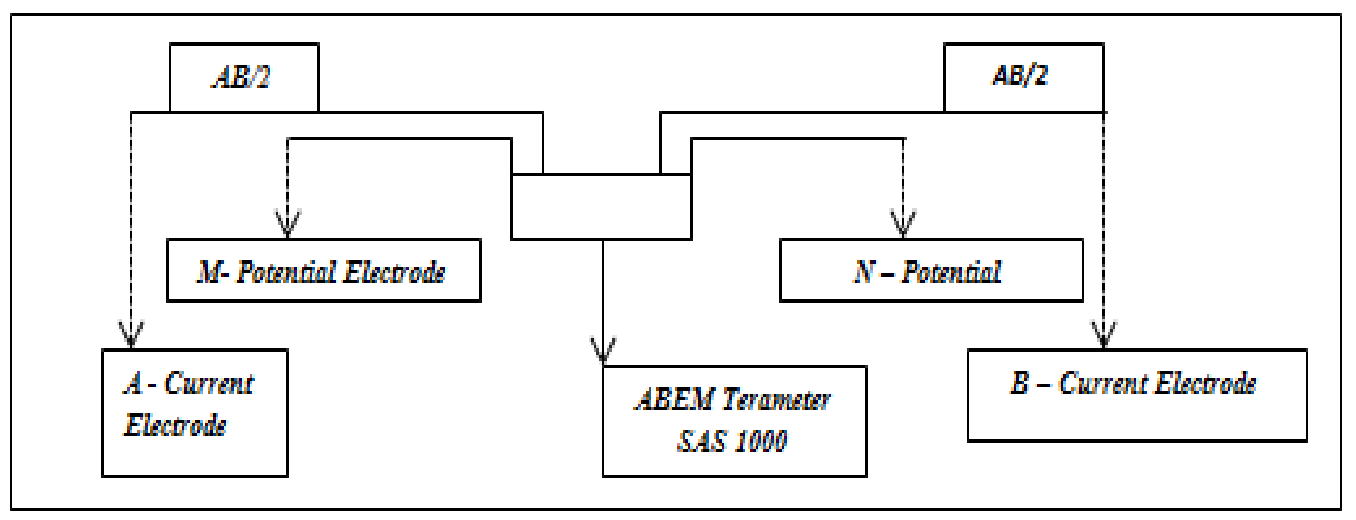

Fig 2:- Schlumberger Configuration Array

$$
\begin{gathered}
K=\frac{A M \times A N}{M N} \times \pi, \text { where } \pi=3.142 \\
\rho=K \times \frac{\Delta V}{I}
\end{gathered}
$$

$A M$ and $A N=$ distance between current electrodes $(m) M N$ $=$ distance between potential electrodes $(m), \Delta V=$ Potential difference (volts) and $I=$ applied current (A), $\rho=$ resistivity (ohm.m)

Some of geophysical devices used to measure these resistivity values can be the ABEM Terameter SAS 400, 800, 1000, 4000; but SAS 1000 was used for the study because of its depth of penetration. The results from the
VES data was modeled using a geophysical software package (IPI2win) and areas of low resistivity values were consider for drilling.

\section{B. Borehole Loggings}

Thirty-five (35) borehole loggings were collected from the study area; however, data suggest that there were about 779 boreholes that existed functionally. Information on the loggings include; drilling penetration rate, depth of water-strike, lithological units, yield and airlift-yield and materials used for the development. Rotary drilling was the prefer drilling method, because it is widely use within the Upper West region of Ghana (crystalline formations). 


\section{Pumping rate}

The duration considered for the purpose of this research was 6 to 9 hours using the Constant Rate Test to study aquifer capacity and avoid over-pumping. This was to avoid large volume tests in barren formations (around Bamahu), areas of marginal wells were pumped between 10 to $13 \mathrm{Lpm}$. Here, the discharging is done constantly for 6 hours and later another 3 hours for the Recovery Test. The 3 hours test was to subject the borehole to a sufficient recovery time frame. Information collected from the pumping test data sheet included; Static Water Level (SWL) in meters, Residual Water Level (RWL) in meters, Yield (Lpm), Dynamic Water Level (DWL) in meters, Average Recovery and height of datum. The yields from the pumpage were computed using:

$$
\text { Borehole yield }(Y)=d q / d t
$$

Where $d q=$ the drawdown and $d t=$ the run - time

\section{FINDINGS AND DISCUSSIONS}

\section{A. Geophysics and Geology}

The distribution of the water-points within the study area is relatively uneven across different districts; this is to unearth the nature and uniqueness of geology. The Vertical Electrical Sounding data was collected using the ABEM Terameter SAS 1000 with $\mathrm{AB} / 2$ distance of $5 \mathrm{~m}$ interval of electrode and MN distance increasing progressively. Table 1 shows the summary of the water-points with resistivity in the area.

\begin{tabular}{|c|c|c|c|c|}
\hline Locations & $\begin{array}{c}\text { Water- } \\
\text { points }\end{array}$ & $\begin{array}{c}\text { Range } \\
\text { Ohm.m }\end{array}$ & $\begin{array}{c}\text { Mean } \\
\text { Ohm.m }\end{array}$ & Remarks \\
\hline Kpaguri & 3 & $542.940-38.48$ & 289.71 & Clay, meta-sedimentary rocks \\
\hline Bamahu & 5 & $246.192-33.974$ & 140.083 & Lateritic-mica, clay, meta-Volcanic \\
\hline Tegberi & 7 & $187.458-62.771$ & 125.115 & Laterite, clay, schist, gneiss \\
\hline Loho & 4 & $104.940-54.833$ & 82.387 & Clay, Laterite, meta-sediments \\
\hline Limanyiri & 3 & $324.879-103.74$ & 214.311 & Lateritic-mica, felsic materials \\
\hline Tumu & 4 & $228.910-89.104$ & 159.007 & Laterite, felsic materials \\
\hline Dondoli & 4 & $2613.55-173.44$ & 1393.50 & Lateritic, meta-volcanic \\
\hline Wechiau & 5 & $116.902-68.337$ & 92.6195 & Clay, meta-sedimentary rock \\
\hline
\end{tabular}

Table 1:- Summary of VES Results and Lithological description in the Upper West Region

The Upper West Region falls under the Pre-cambrian formation popularly known as the Birimian, this geological formation is the makeup of meta-volcanics rocks, metasedimentary rocks, basaltic flows, granitoids and metamorphosed rocks (GGS, 2010). The Wa municipality (Kpaguri and Limanyiri) generally has thick granitoids as base-rock of Mica-homblende-boitite mineralization, this kind of rock undergoes shear stressing to cause faulting and fracturing within it. The presence of mica shows residual laterite formation and also clay mineral deposit within Bamahu and Limanyiri. These fractures serve as pathways and high reserves for underground resource, the VES values for Wa municipality depict meta-sedimentary rocks, this can be evident from the 35 drill $\log$ of boreholes which includes kpaguri and limanyiri. The drill logs show a formation of phyllitic sediments (meta-sedimentary) which accounts for the VES values of 543.940 ohm.m - 38.34 ohm.m. The VES values of 246.192 ohm.m - 33.974 ohm.m around Tegberi, Wadhi and Loho (Jirapa road) show a define geology of the Birimian. These areas are predominantly of meta-volcanics and metarmphosed granitoids. The regolith has an average thickness of $22 \mathrm{~m}$ with laterites and transported material. The VES values ranges from 187.458 - 62.771 ohm.m depicting crystalline formations but isolated areas of high motten deposit. Areas around Bamahu and Dondoli exhibited a formation of meta-volcanic which is as a result of volcanism that might have occurred over centuries, thick granitic base-rock accounts for the VES data ranging from 246.192ohm.m - 33.974ohm.m. The Birimian formation has a borehole success rate of $96 \%$ with average depth of $65 \mathrm{~m}$ (DapaahSiakwan and Agyekum 2008). The presence of high clay materials can be attributed to the feldspatic mineral in the base-rock. In regolith geology, the end-product of weathering of felsic mineral rock is clay while the quartz ends up as quartzitic sand (Arhin, 2015)

\section{B. Spatial distribution of Resistivity (VES)}

The study of groundwater and rock resistivity is of great importance to this research, the groundwater resistivity in this study was determined to be between $38.480 \mathrm{ohm} . \mathrm{m}-103.740 \mathrm{ohm} . \mathrm{m}$. The depth of saturation was used in the estimation of the groundwater storage capacity as well as the extractable storage, it was found to range from $13.79 \mathrm{~m}-16.27 \mathrm{~m}$. Mohamaden and Ehab, 2017; research findings from the Shalateen area around the Red Sea (Southeastern part of the Eastern Desert) estimated groundwater resistivity to be within 38.6 ohm.m - 98.4 ohm.m and depth ranging from $1.31 \mathrm{~m}-19.0 \mathrm{~m}$. The similarity in his work and this research is they have same geology. The maximum and minimum resistivity in the geological units is from 2613.55 ohm.m - 33.974 ohm.m. Figure 3 is a spatial distribution map of resistivity values across the study area, this is to give a picture of how the resistivity are distributed and relates to the geology and hydrogeology of the area. Generally the area under study shows ununiformed distribution of the Vertical Electrical Sounding (VES) values. 


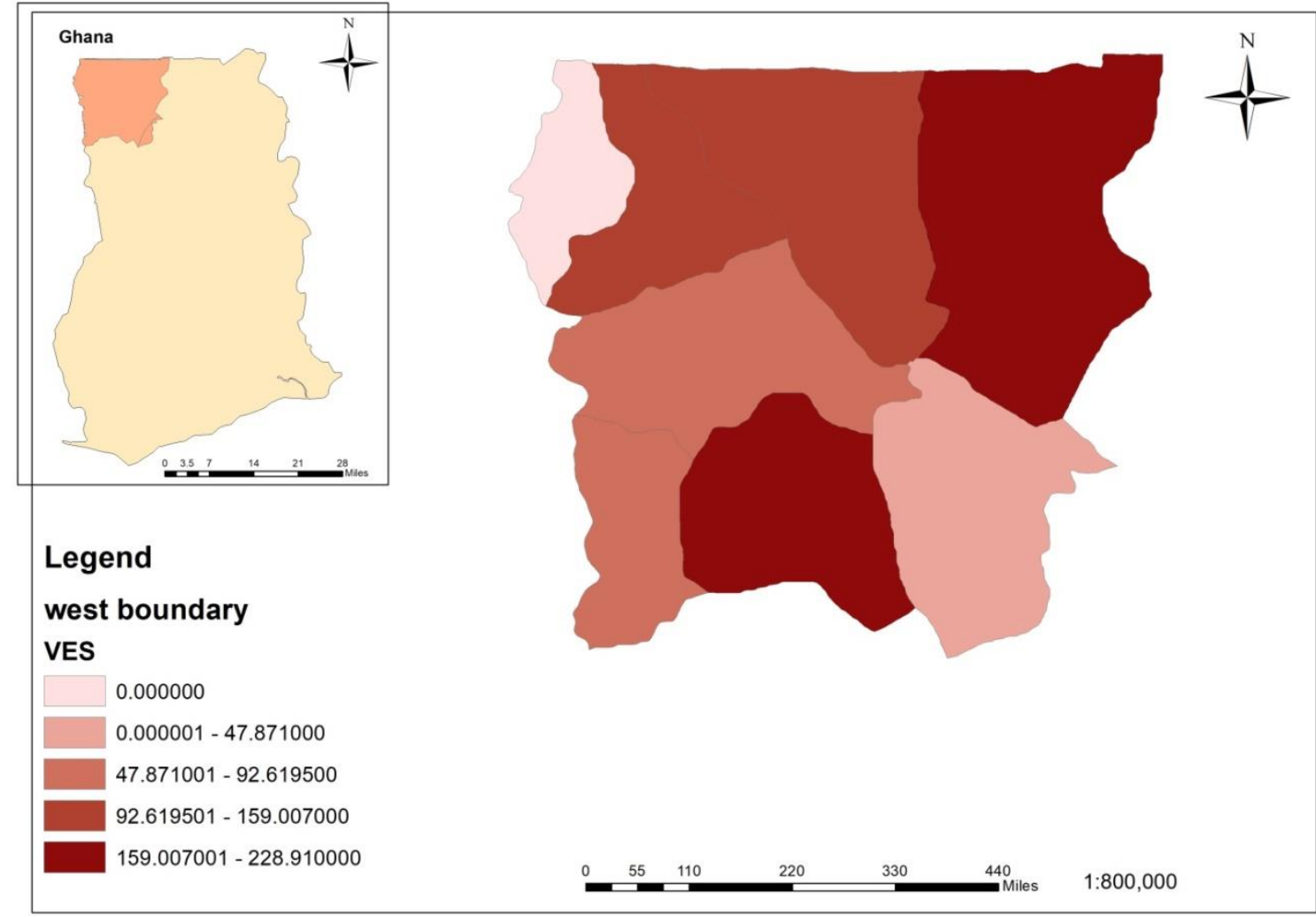

Fig 3:- Spatial distribution of resistivity in the study area

\section{Boreholes successes (Performance)}

A total of thirty-five (35) successful boreholes were considered in this research, they were drilled in both the upper and the lower Birimiain. Seventeen (17) of the boreholes were drilled in the meta-volcanic formation with a $99 \%$ success while Eighteen (18) of the boreholes were drilled in the meta-sedimentary formation with a success of $94 \%$. There had a combine success rate of 97\% which is more than the Sub-Saharan Africa success of 93\% (Carter and Bevan, 2008).

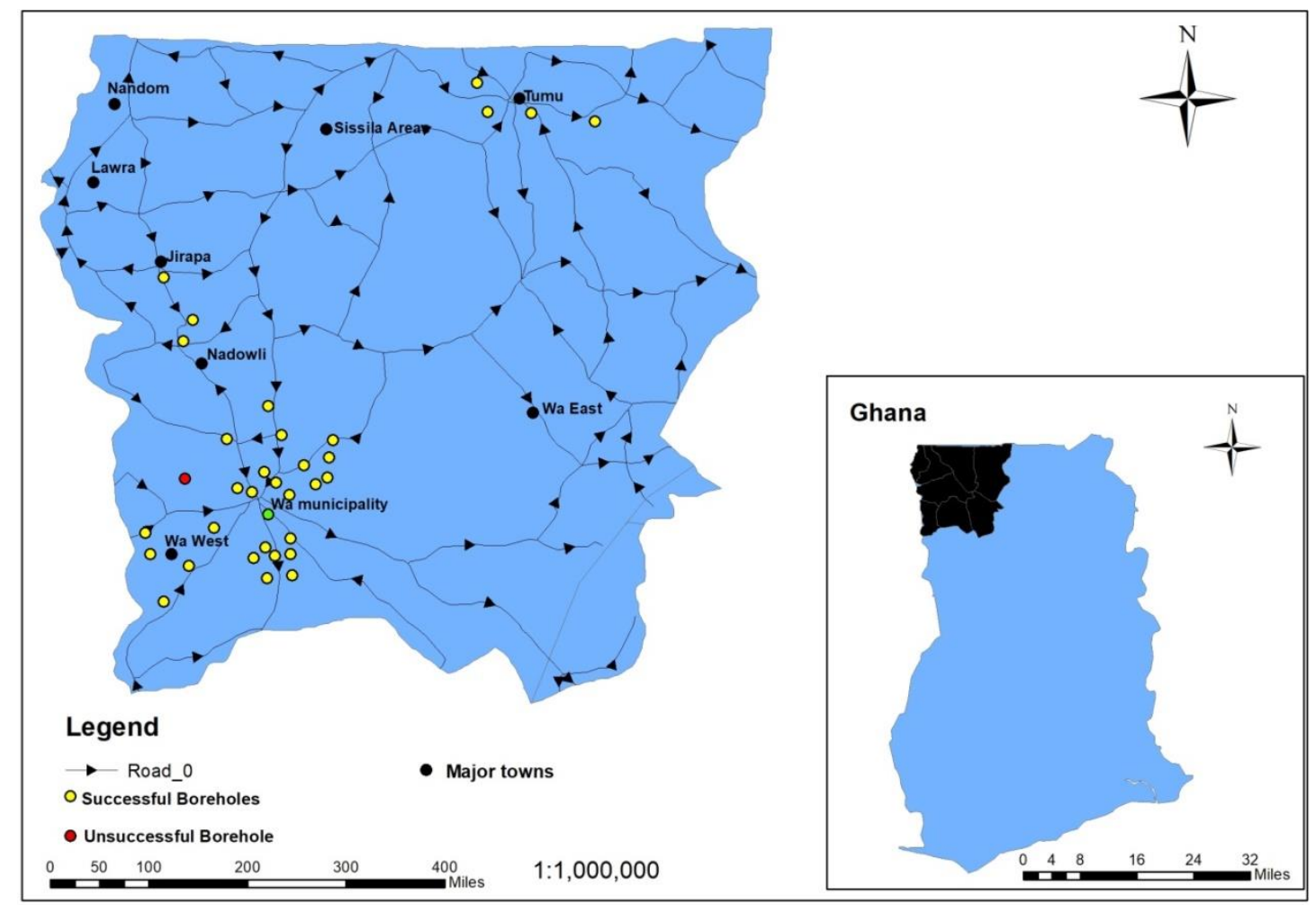

Fig 4:- Map of Borehole sites 
The research targeted areas of high borehole success rate in order to minimise the gap that may affect the calculation of the groundwater storage, this value tells the successes and availability of groundwater within Upper West Region and its tendency of supplying water for irrigation and strengthening the backbone of agricultural production. Another parameter that was estimated to authenticate the $97 \%$ success rate is the extractable and groundwater storage capacity. The Groundwater Storage in the area was computed using Equation 3a (Schoeller, 1967).

$$
Q_{s}=(P-\%) \times \emptyset \times H \times A
$$

Where $\left(Q_{S}\right)$ is The Total Groundwater Storage, $(P$ $-\%)=$ Groundwater Coverage, $(\varnothing)$

= Effective Porosity, $(D)$

= Saturated Depth,

(A) Extent of Study Area

But Porosity $(\varnothing)=V_{t} / V_{v} ; \mathrm{V}_{\mathrm{v}}$ is the void volume and $\mathrm{V}_{\mathrm{t}}$ is the total volume of unconsolidated material (Bear, 1979).

$$
Q_{e}=(P-\%) \times S_{y} \times H \times A
$$

Where $\left(Q_{e}\right)$ is The Extractable Groundwater Amount, $(P$ $-\%)=$ Groundwater Coverage, $\left(S_{y}\right)$ $=$ Specific Yield, $(D)=$ Saturated Depth, (A) Extent of Study Area

Where, $S_{y}=V_{w d} / V_{t}$, Where $\mathrm{V}_{\mathrm{wd}}$ is the volume of water drained and $V_{\mathrm{T}}$ is the total rock or material volume (Bear, 1979).

Measurements from ground surface to the groundwater surface were taken to be the Static water level (SWL) and from water surface to weathered depth was computed from table 2. The saturated depth was the difference of weathered depth and depth to groundwater surface. Boreholes were deemed successful if the yield was $\leq 13 \mathrm{Lpm}$ and unsuccessful if it yield $\geq 13 \mathrm{Lpm}$ for this study. Parameters such as total weathered depth and depth to

\begin{tabular}{|c|c|c|c|}
\hline Parameters & Meta-Sedimentary & Meta-Volcanic & $\begin{array}{l}\text { Mean } \\
\text { values }\end{array}$ \\
\hline Total Weathered Depth (D) m & 28.5 & 25.5 & 27.0 \\
\hline Depth of groundwater surface (h) $\mathrm{m}$ & 12.23 & 11.71 & 11.97 \\
\hline Saturated Depth (H=D-h) m & 16.27 & 13.79 & 15.03 \\
\hline Number of Boreholes (N) & 18 & 17 & 35 \\
\hline Number of successful (S) & 17 & 17 & 34 \\
\hline Number of unsuccessful (U) & 1 & 0 & 1 \\
\hline Groundwater Coverage $(\mathrm{P}-\%)=\mathrm{S} / \mathrm{N}$ & 0.94 & 0.99 & 0.97 \\
\hline
\end{tabular}
water surface were determined from the drilled logs.

Table 2:- Summary of Borehole Results from the Upper West Region

The quantification of Groundwater Storage Capacity was based on the data gathered from the 35 borehole logs using equation $3 \mathrm{a}$ and $3 \mathrm{~b}$. Taking Effective Porosity (wellinterconnected-pores) to be $5 \%$ and Specific Yield to be $2 \%$ respectively (Acworth, 1987 and Asomaning, 1993) with an area of 18, $476 \mathrm{~km}^{2}$ (Extent of Study Area). The Groundwater Coverage (percentage) was attained rationing the number of successful boreholes to the number of boreholes studied $[(\mathrm{P}-\%)=\mathrm{S} / \mathrm{N}]$. After thorough computation, the Total Groundwater Storage and Extractable Groundwater was approximately $134.9 \times 10^{3}$ $\mathrm{km}^{3}$ and $53.23 \times 10^{3} \mathrm{Km}^{3}$ correspondingly. The Essence of computing the Extractable Groundwater Amount is to ensure that over-abstraction is avoided, prevent aquifer damages, aquifer contamination and aquifer stress. The groundwater potential within the Upper West Region is exceedingly enough to support the idea of this paper. The computation reflects areas of high groundwater yield; this is to make these sites suitable and favourable for the purpose of irrigated-agriculture.

\section{The Pumping Test (Rate)}

The pumping test results show the quantity of water that was discharged from the boreholes; the yield suggests that there is reasonably enough water for future irrigation projects. The pumping test combined with the geophysical test will predict sites favorable for irrigational programs for the future if this research is to be manifested. Table 3 presents the summary of pumping test results for the Upper West Region of Ghana.

\begin{tabular}{|c|c|c|c|c|}
\hline & Borehole depth (m) & Borehole Discharge (LPM) & SWL \\
\hline Regions & $\begin{array}{c}\text { Boreholes } \\
\text { Analyzed }\end{array}$ & Range & Range & $18.75-5.65$ \\
\hline Meta-Sedimentary & 18 & $65-55$ & $300-11$ & $20.60-12.45$ \\
\hline Meta-Volcanic & 17 & $85-55$ & $260-140$ & Range \\
\hline
\end{tabular}

Table 3:- Summary of Pumping Test Results from the Upper West Region. 
From table 3, the values for the discharge within Upper West Region shows that there is enough groundwater to support the idea that groundwater can be another alternative of water supply for irrigated agriculture, discharge of 300 LPM and 260 LPM are correspondingly high. Communities along the Jirapa road (Tegberi, Loho, Wadhi) had an average airlift yield of 290 LPM. The Static water level (SWL) shows areas of shallow and deep groundwater resources (Forkuor et al, 2013). The meta-sedimentary formation would have deeper groundwater depth while the meta-volcanic zones will probably have shallow groundwater depth within the research area.

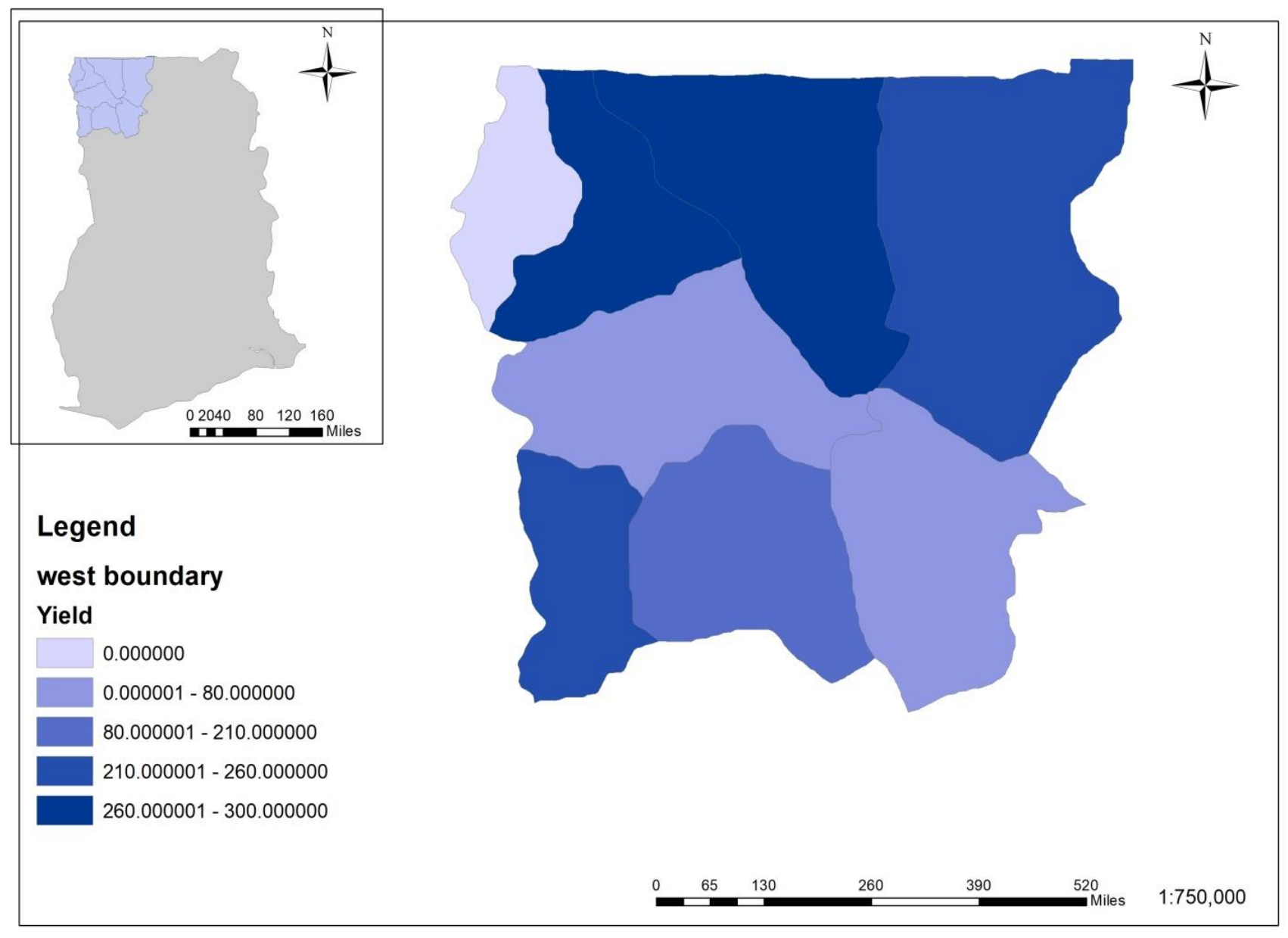

Fig 5:- Spatial distribution of borehole yield

Figure 5 gives more insight on Figure 7 which was adapted from (Forkuor et al., 2013) in a research he conducted within the three Northern Regions title "Modeling potential areas of groundwater development for agriculture in northern Ghana using GIS/RS". The focus area in Figure 7 is the square drawn on the map showing areas of high groundwater potential; these areas are Wa, Jirapa and Tumu. This present study shows a spatial map of yield variation with similarly deductions from Figure 7; depicting areas of high yield, these areas in the study area; Wa municipality, Jirapa, Tumu and the Sissila areas.

\section{E. Variation of borehole depth and yield}

Figure $6 \mathrm{a}$ and $6 \mathrm{~b}$ both show a weak correlation between borehole depth and yield in the meta-volcanic and meta-sedimentary formation. This can be linked to the fact that the meta-volcanic and meta-sedimentary falls under the Birimian formation which are partially crystalline in nature and have same attributes in the weathering process. Also they both have unique groundwater condition, since they have same aquifer: which is the sedimentary fractured type with high potential. 


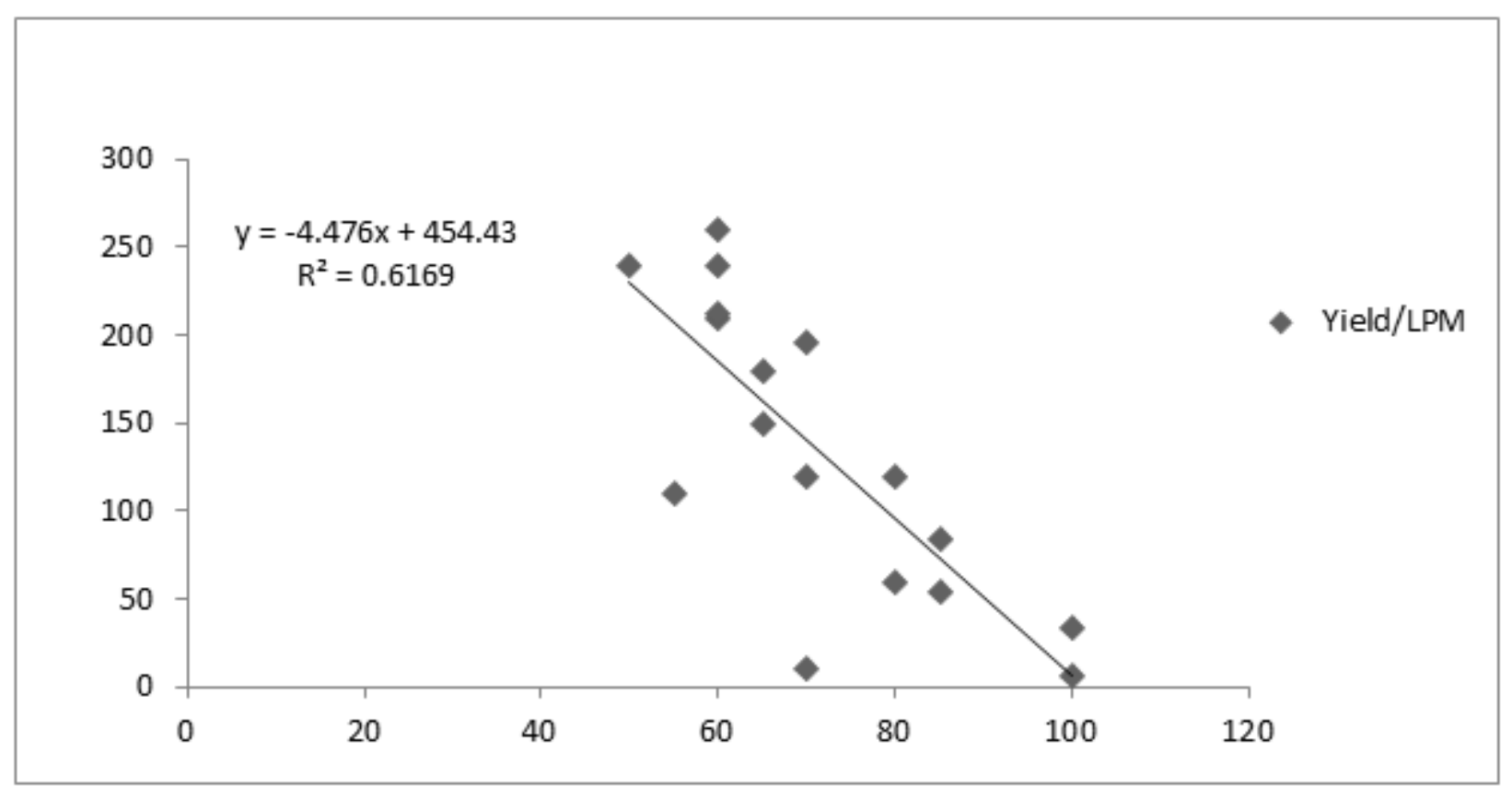

Fig 6a:- Variation of Yield with Depth in the Meta-Volcanic Formation

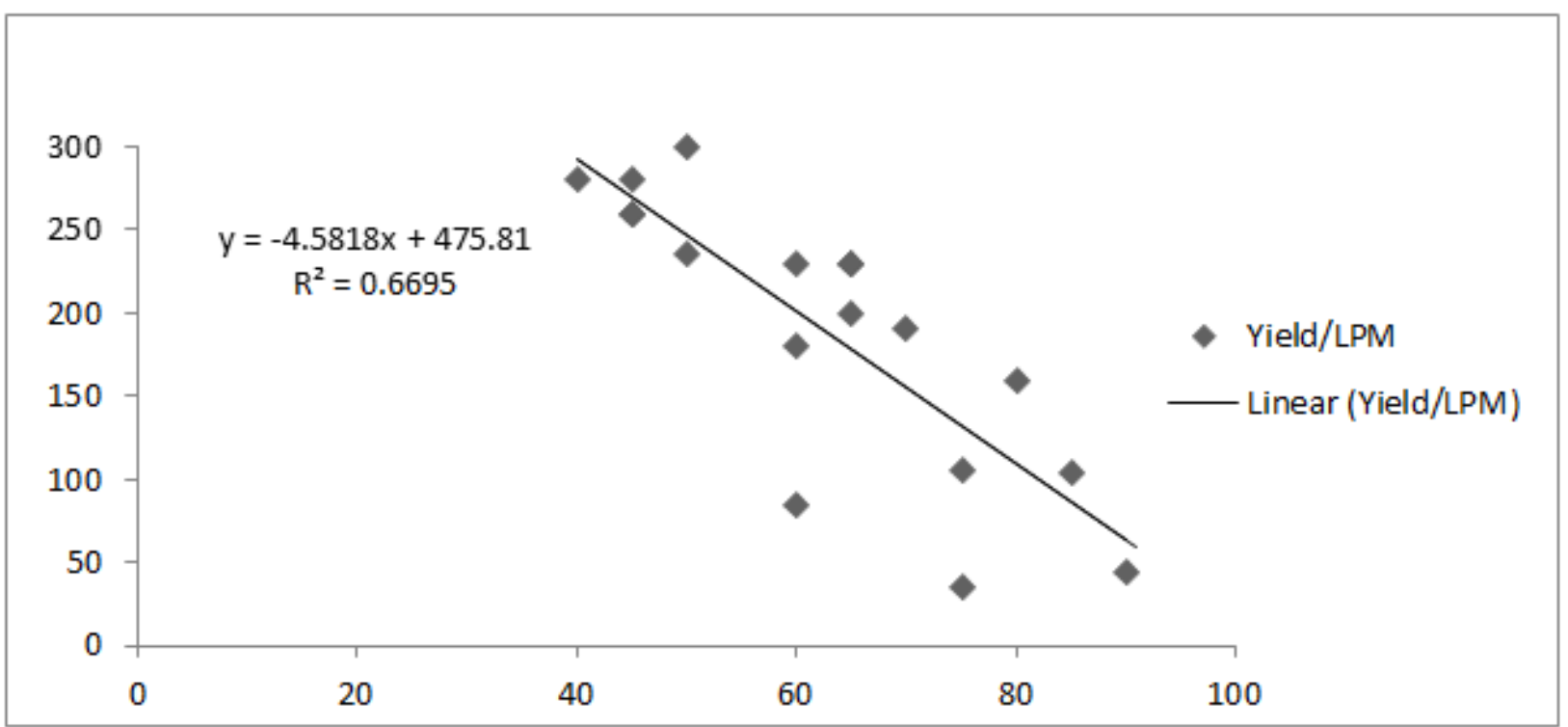

Fig 6b:- Variation of Yield with Depth in the Meta-Sedimentary Formation

\section{F. Potential Viable Sites in the Research Area}

The map (Figure 7) shows areas of high groundwater potential, the demarcated area (Northwestern corner of the Map) is the area of focus. The green-portions on the map in figure 7 (Forkuor et al., 2013) reflect areas of high potential compared to figure 5 which is marked by the violet-portions (present study). In the future where the groundwater irrigation is to be manifested Fig 5 and 7 can serve as a guiding block. In the Upper West Region areas around the Wa municipal (Kpaguri, Limanyiri, Dondoli), on the Jirapa road (Tegberi, Loho), Tumu and Wa West (Wechiau) are promising sites that may be suitable and favourable for irrigated agricultural activities. 
ISSN No:-2456-2165

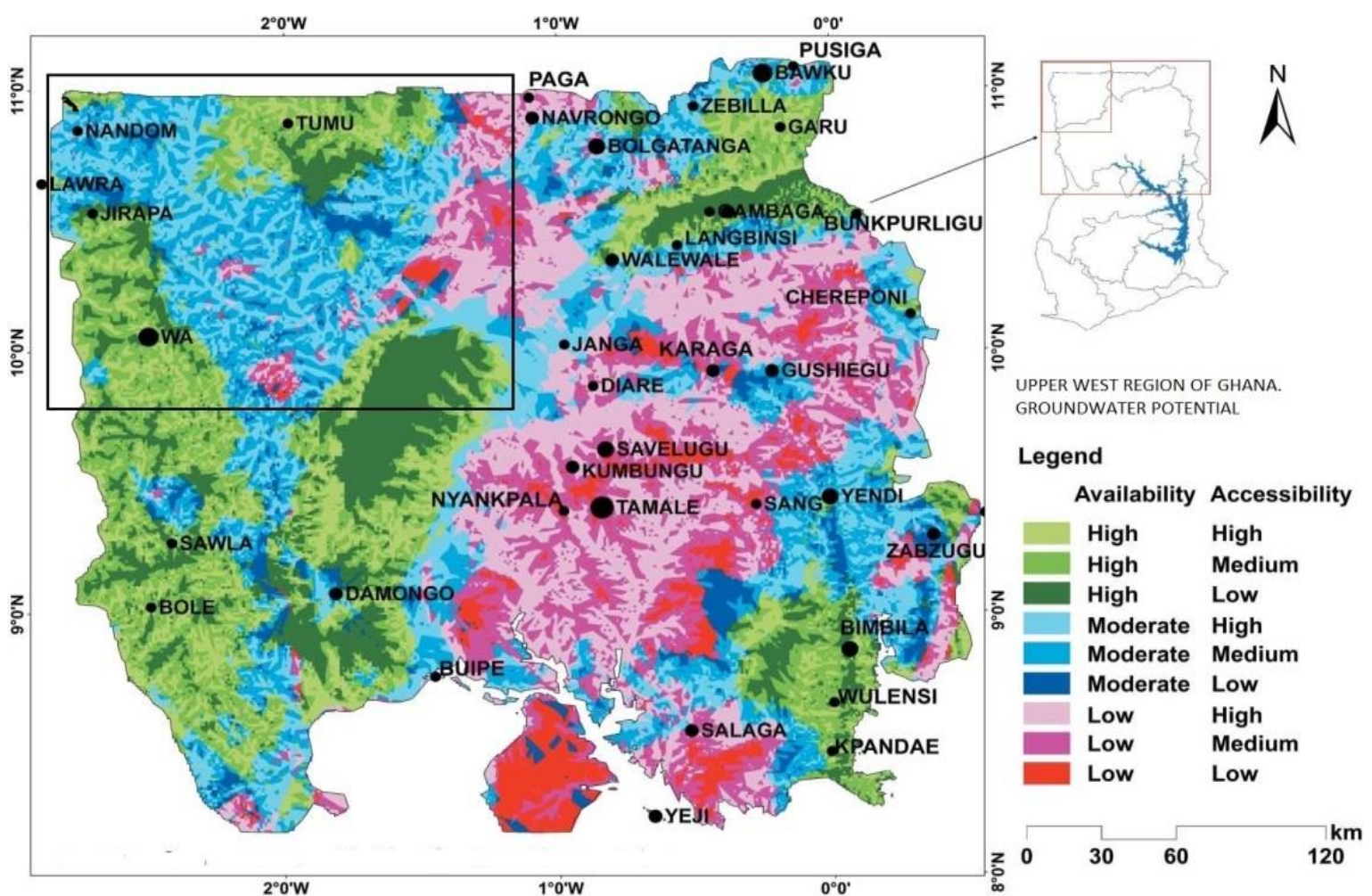

Fig 7:- A Map of the Study Area Showing Areas of High Groundwater Potential (Adapted from Forkuor et al., 2013)

\section{CONCLUSION}

The data was collected from recent sited and drilled boreholes within May - July 2016 and January - May 2019, it was analyzed using both qualitative and quantitative methods to estimate and predict sites of high groundwater potential. The geophysical data showed that the Upper West Region is underlain with the Birimian rocks which comprises of Meta-sedimentary (Phyllite, Slate, Schist), and Meta-Volcanic (granitoids, gneiss) while the overburden has an average thickness of $22 \mathrm{~m}$ which is made up of laterite and clay. The Groundwater Storage and the Extractable Groundwater in Upper West Region were estimated to be approximately $134.9 \times 10^{3} \mathrm{~km}^{3}$ and $53.23 \mathrm{x}$ $10^{3} \mathrm{~km}^{3}$ respectively. The pumping rate showed that large quantity of groundwater discharged from the boreholes, hence the exploration of groundwater as an alternative water supply for irrigation and agricultural production within the Upper West region may be feasible.

\section{REFERENCES}

[1]. Adelana, S.M.A., MacDonald, A.M., 2008. Groundwater research issues in Africa. In: applied Groundwater Studies in Africa. Iah Selected papers on hydrogeology, Volume 13 (Adelana S. M.A and MacDonald A. M. eds.). CrC press/Balkema, Leiden, the Netherlands.

[2]. Acheampong, S.Y., Hess, J.W., 1998. Hydrogeologic and hydrochemical framework of the shallow groundwater system in the southern Voltaian Sedimentary Basin, Ghana. Hydrogeology Journal 6 (4) : 527-537.
[3]. Acworth, R.I., 1987. The development of crystalline basement aquifers in a tropical environment. Quarterly Journal of Engineering Geology \& Hydrogeology 20 (4) : 265272.

[4]. Arhin, E., Jenkin, R.T., Dickson, C., Prosper, M.N., 2015. Regolith mapping of deeply weathered terrain in savannah regions of the Birimian Lawra Greenstone Belt of Ghana.

[5]. Asomaning, G. 1993, Groundwater resources of the Birim basin in Ghana. Journal of African Earth Sciences 15 (3-4): 375-384.

[6]. Bouraoui, F., Vachaud, G., Li, L. Z. X., Le Treut, H. and Chen, T. 1999, Evaluation of the impact of climate changes on water storage and groundwater recharge at the watershed scale, Climate Dynamics, Vol. 15, pp. 153-161

[7]. Carter, R.C., and Bevan, J.E., 2008. Groundwater Development for poverty alleviation in sub-Saharan Africa. In: Applied Groundwater Studies of Africa. IAH selected papers on Hydrogeology. Volume 13 (ed. By S. M. A and A.M MacDonald) CRC Press/Balkema, Leiden, The Netherlands.

[8]. Dapaah-Siakwan, S., Agyekum, W.A., 2008. The occurrence of groundwater in Northeastern Ghana. Applied groundwater studies in Africa Journal, 199 214

[9]. FAO (Food and Agriculture Organization), 2003. Review of world water resources by country. Rome: Food and Agriculture Organization of the United Nations, Water Report 23. 
[10]. Forkuor, G., Pavelic, P., Asare., and Obuobie, A., 2013. Modelling potential areas of groundwater development for agriculture in northern Ghana using GIS/RS, Hydrological Sciences Journal, 58:2, 437451 ,

[11]. Giordano M., 2006. Agricultural groundwater use and rural livelihoods in Sub-Saharan Africa: a first cut assessment, Hydrogeology Journal, 14(3):310-318.

[12]. MacDonald A.M., Bonsor, H., Dochartaigh, B., Taylor, R., 2012. Quantitative maps of groundwater resources in Africa. Environmental research letters, volume - 7 .

[13]. Masiyandima, M and Giordano M. 2007. Sub-Saharan Africa: opportunistic exploitation. In: the agricultural groundwater revolution: opportunities and threats to development. Comprehensive assessment of Water Management in agriculture Series 3 (Giordano $M$ and Villholth K. eds). Wallingford: IWMI and $\mathrm{CaB}$ International.

[14]. Mdemu, M., Laube, W., and Barry, B., 2010. Temporal water productivity of tomato irrigated from a small reservoir and hand-dug-wells in dry season cropping in the Upper East Region, Ghana. Journal of Applied Irrigation Science, 45 (1), 75-93.

[15]. Mohamaden, M.I.I., Ehab, D., 2017. Application of Electrical Resistivity for groundwater exploration in Wadi Rahaba, Shalateen, Eqypt. NRIAG Journal of Astronomy and Geophysics.

[16]. Nathan, R.R., Harris, F.R.,1970. The occurrence of groundwater. Prepared for the Ministry of Finance and Economic Planning, Nathan Consortium, Accra, February 1970, 33 p.

[17]. Pavelic, P., Giordano, M., Keraita, B., Ramesh, V., Rao, T., 2012. Groundwater availability and use in SSA countries, A review of 15 countries. Colombo, Sri Lanka: International Water Management Institute (IWMI).

[18]. Schoeller, H., 1967. Quantitative evaluation of groundwater resources. In: Methods and Techniques of Groundwater Investigation and Dev.. UN Water Resources Series 33: 21-44

[19]. Soil Research Institute, 2006. Soil map of Ghana. Council for Scientific and Industrial Research, data obtained directly from SRI personnel in August 2006, publishing date unknown.

[20]. Trenberth, K. E., Smith, L., Qian, T., Dai. A., (2007). Estimates of the Global Water Budget and Its Annual Cycle Using Observational and Model Data. National Center for Atmospheric Research,* Boulder, Colorado. JOURNAL OF HYDROMETEOROLOGY - SPECIAL SECTION

[21]. United Nations Economic Commission for Africa (UNEC) (2011), Agricultural Water Management in the Context of Climate Change in Africa, working paper. 